\title{
pH-monitoring in mortar with thermally-oxidized iridium electrodes
}

\author{
Yurena Seguí Femenias ${ }^{\mathrm{a}^{*}}$, Ueli Angst ${ }^{\mathrm{a}}$, Bernhard Elsener ${ }^{\mathrm{a}, \mathrm{b}}$ \\ ${ }^{a}$ ETH Zürich, Institute for Building Materials (IfB), Stefano-Franscini-Platz 3, 8093 Zurich, Switzerland \\ ${ }^{\mathrm{b}}$ University of Cagliari, Department of Chemical and Geological Sciences, 09100 Monserrato (CA), Italy
}

Received: 21 August 2017 / Accepted: 25 December 2017 / Published online: 30 December 2017

(C) The Author(s) 2017. This article is published with open access and licensed under a Creative Commons Attribution 4.0 International License.

\begin{abstract}
The $\mathrm{pH}$ of the concrete pore solution plays a vital role in protecting the reinforcing steel from corrosion. Here, we present results from embeddable $\mathrm{pH}$ sensors that permit the continuous, in-situ monitoring of the $\mathrm{pH}$ in the concrete pore solution. These are potentiometric sensors, based on thermallyoxidized iridium/iridium oxide $\left(\mathrm{IrO}_{\mathrm{x}}\right)$ electrodes. We propose an iterative calculation algorithm taking into account diffusion potentials arising from $\mathrm{pH}$ changes, thus permitting the reliable, non-destructive determination of the pore solution $\mathrm{pH}$ over time. This calculation algorithm forms an essential part of the method using $\mathrm{IrO}_{\mathrm{x}}$ electrodes. Mortar samples were exposed to accelerated carbonation and the $\mathrm{pH}$ was monitored at different depths over time. Comparative tests were also performed using thymolphthalein $\mathrm{pH}$-indicator. The results from the $\mathrm{pH}$ sensors give insight in the carbonation process, and can, in contrast to thermodynamic modelling and titration experiments, provide insight in kinetic processes such as transport and phases transformations. It was found that the front at which the $\mathrm{pH}$ is decreased from initially 13-14 down to 12.5 can be significantly ahead of the common carbonation front corresponding to $\mathrm{pH}$ 9-10. This has major implications for laboratory testing and engineering practice.
\end{abstract}

Keywords: Iridium/iridium oxide electrode; pH sensor; Carbonation monitoring; Non-destructive technique

\section{Introduction}

Reinforced concrete is the most common building material used in civil engineering. Durability of this material can, however, be compromised due to the corrosion of reinforcement steel. In fact, in many countries this is considered the most important degradation mechanism for reinforced concrete structures [1].

The $\mathrm{pH}$ of the concrete pore solution is in the range $\mathrm{pH}$ 1314 due to the alkalinity provided by the dissolved sodium and potassium oxides present in Portland cement [2, 3]. At these high $\mathrm{pH}$ values, reinforcing steel is protected from corrosion by a thin oxide layer, i.e., the passive layer, spontaneously formed on the steel surface [4]. However, the reaction of $\mathrm{CO}_{2}$ from the atmosphere with the alkaline components in the concrete pore solution and the $\mathrm{Ca}(\mathrm{OH})_{2}$ (Portlandite) in the cement paste, decreases the $\mathrm{pH}$ to levels below $9[4,5]$. As a result, when the carbonation front reaches the steel, it may be depassivated and in presence of oxygen and moisture, reinforcement corrosion starts. This is known as carbonation-induced corrosion [4].

As carbonation-induced corrosion is accompanied by a decrease in the alkalinity of the concrete pore solution, knowledge of the $\mathrm{pH}$ in concrete is essential. Common methods to determine the $\mathrm{pH}$ in concrete are destructive, do not provide continuous information over time and have limited spatial resolution [6, 7]. The most established method in practice is based on spraying an indicator solution [8], such as phenolphthalein or thymolphthalein, on a freshly exposed concrete surface. This test indicates the depth of carbonation, which is defined as the depth at which the $\mathrm{pH}$ gradient meets the indicator's characteristic $\mathrm{pH}$. Typically, the carbonation front is understood as the front at which the $\mathrm{pH}$ drops below $\mathrm{pH} 9$ or 10 . The indicator spray test does not give any information about the $\mathrm{pH}$ distribution behind and in front of the "carbonation front". Thus, this method does not indicate a decrease in $\mathrm{pH}$ from the initial value (typically $\mathrm{pH}$ 13-14) until $\mathrm{pH} 9-10$ is reached. Only recently, by using several indicators, the spatial distribution of $\mathrm{pH}$ levels between $\mathrm{pH} 13.5$ and 11 was mapped [9]. However, this approach is laborious. Other methods to determine the $\mathrm{pH}$ of concrete are pore solution expression or crushing concrete samples and exposing them to a leaching agent [6, 7]. While these approaches may provide more accurate results than indicator tests, they are time consuming and present difficulties at low moisture levels as well as in the presence of sharp $\mathrm{pH}$ gradients, where limitations regarding the minimum sample volume needed render the application of these methods impossible.

Embedded, non-destructive $\mathrm{pH}$ sensors in concrete, however, would allow the permanent monitoring of $\mathrm{pH}$ over

* Corresponding author: Yurena Seguí Femenias, Tel. +41 4463376 68, E-mail: syurena@ethz.ch 
time $[10,11]$. Different sensors have been developed for this purpose; among them, fibre-optic sensors and metal oxide potentiometric sensors emerge as the most promising [7]. Fibre optic sensors have low price, general chemical stability, good spatial resolution (depending on the size of the sensor, usually in the range of a few $\mathrm{mm}$ ) and good accuracy (usually 0.1-0.6 pH units) [7]. However, they present severe limitations for applications in concrete including short life spans, narrow pH-range that can accurately be measured (e.g., the reported results are usually within a range of $2 \mathrm{pH}$ units), leaching of the dye used in this type of sensors, and chemical instability at high $\mathrm{pH}$ values. Moreover, few studies exist where the $\mathrm{pH}>13$ has been measured [7].

Concerning potentiometric sensors, Iridium/Iridium oxide $\left(\mathrm{IrO}_{\mathrm{x}}\right)$ electrodes showed promising results in aqueous solution [12-15] in terms of high stability in a broad $\mathrm{pH}$ range, accuracy, and insensitivity to the oxygen content. Moreover, the size of the sensors is relatively small, i.e., wire diameters are $<1 \mathrm{~mm}$, and thus permit high spatial resolution for the application in concrete. However, only a few studies regarding the use of $\mathrm{IrO}_{x}$ embedded in mortar or concrete have been made $[16,17]$. Despite the promising results in the reported works, the $\mathrm{pH}$ values measured were always above $\mathrm{pH} 11.5$ and no data regarding the $\mathrm{pH}$ evolution while cement paste is carbonated was presented.

In this work, we report the $\mathrm{pH}$ response of $\mathrm{IrO}_{\mathrm{x}}$ electrodes embedded at different depths in mortar samples that were exposed to accelerated carbonation. These sensors allowed monitoring the $\mathrm{pH}$ of the pore solution continuously while the cement paste was carbonated. Comparative tests were also conducted using thymolphthalein $\mathrm{pH}$-indicator. The findings have major implications for research and practice.

\section{Materials and methods}

\section{1 $\mathrm{pH}$ determination with thymolphthalein $\mathrm{pH}$-indicator}

Mortar cubes $\left(4 \times 4 \times 4 \mathrm{~cm}^{3}\right)$ were produced with mix proportions cement/water/sand 1: 0.5: 2 with CEM I 52.5 and sand size $<1 \mathrm{~mm}$. They were cured for one week at $95 \% \mathrm{RH}$ and $21^{\circ} \mathrm{C}$. After one week of exposure to laboratory conditions (ca. $50 \% \mathrm{RH}$ and $21^{\circ} \mathrm{C}$ ), all the surfaces (except one) were painted with an epoxy-resin. The samples were then placed in a carbonation chamber $\left(65 \% \mathrm{RH}, 21^{\circ} \mathrm{C}\right.$ and $4 \%$ $\mathrm{CO}_{2}$ ) so one-dimensional carbonation occurred though the non-coated surface.

Mortar cubes were taken from the carbonation chamber after different exposure times and split perpendicular to the surface of $\mathrm{CO}_{2}$ ingress. The carbonation depth was then determined by means of the indicator spray test. For that, thymolphthalein solution was prepared by dissolving $0.04 \mathrm{gr}$ of thymolphthalein in $50 \mathrm{~mL}$ of $95 \%$ ethanol, diluted to 100 $\mathrm{mL}$ of deionized water. The prepared thymolphthalein solution was sprayed on the two freshly broken mortar surfaces so the depth at $\mathrm{pH}$ 9-10 was determined [8]. The carbonation depth was determined from the average of 8 measurements of the depth of color change (4 measurements for each exposed surface).

\section{$2.2 \mathrm{pH}$ monitoring with embedded iridium/iridium oxide $\left(\mathrm{IrO}_{\mathrm{x}}\right)$ electrodes}

\subsubsection{Iridium/iridium oxide $\left(\right.$ IrO $\left._{x}\right)$ electrodes}

Thermally oxidized iridium wires were produced based on the procedure reported in $[12,18,19]$. After production, the $\mathrm{IrO}_{\mathrm{x}}$ electrodes were conditioned in alkaline solution $(\mathrm{pH}$ $13.5-\mathrm{pH}$ 9) for 2-6 months and then individually calibrated in solution of $\mathrm{pH}$ values ranging from 13.5 to 9 , as recommended in [20]. The potential response to $\mathrm{pH}$ of the produced $\mathrm{IrO}_{\mathrm{x}}$ electrodes can be written as:

$E_{\mathrm{IrO}_{\mathrm{x}}}=E_{\mathrm{IrO}_{\mathrm{x}}}^{0}-b \cdot p H$

where $E_{\mathrm{IrO}_{\mathrm{x}}}^{0}$ is the electrode standard potential and $b$ the potential-pH $(E-p H)$ slope. Note that each electrode's standard potential and E-pH slope was obtained from separate individual pre-calibration. More details regarding the production protocol, conditioning and potential response are given in Ref. [20].

Each $\mathrm{IrO}_{\mathrm{x}}$ electrode was mounted inside a rigid stainless steel tube (ca. $5 \mathrm{~cm}$ long and $2 \mathrm{~mm}$ in diameter), leaving only approx. $5 \mathrm{~mm}$ length of the $\mathrm{IrO}_{x}$ electrode protruding from the steel tube (Fig. 1). This ensures accurate positioning of the $\mathrm{pH}$-sensor at the desired cover depth. The stainless steel tube and the $\mathrm{IrO}_{x}$ wire were electrically isolated with a Teflon tube (ca. $6 \mathrm{~cm}$ long and $1 \mathrm{~mm}$ in diameter) slightly longer than the steel tube. Front and back ends were sealed with an epoxy resin. Epoxy resin had also been applied, after production, to the tip of the $\mathrm{IrO}_{\mathrm{x}}$ electrode because it was suspected that some adherence problems of the oxide layer could happen on the edges [20].

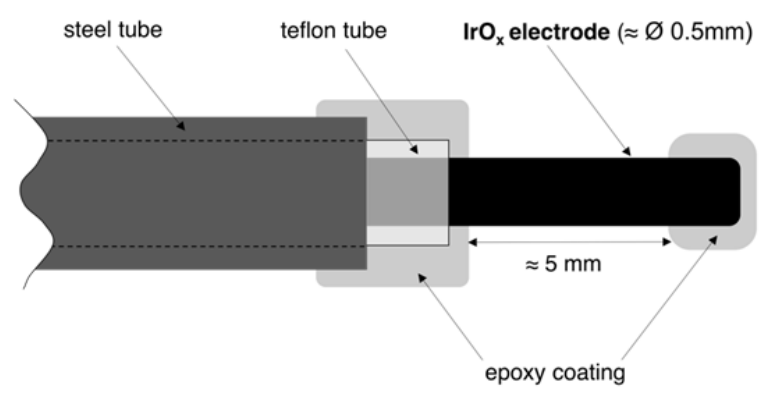

Figure 1. Schematic representation of $\mathrm{IrO}_{\mathrm{x}}$ sensors embedded in mortar. The $\mathrm{pH}$ sensitive part ( $\mathrm{IrO}_{\mathrm{x}}$ electrode) is mounted in a stainless steel tube (outer diameter approx. $2 \mathrm{~mm}$ ) to enable accurate positioning in the mortar/concrete. A Teflon tube electrically separates the steel and the $\mathrm{IrO}_{\mathrm{x}}$. The ends are coated with an epoxy resin for sealing purposes.

\subsubsection{Set-up and measurement procedure}

Three rectangular mortar prisms $\left(5 \times 7.5 \times 7.5 \mathrm{~cm}^{3}\right)$ with embedded $\mathrm{IrO}_{x}$ sensors were produced (Fig. 2). In total, six $\mathrm{IrO}_{\mathrm{x}}$ sensors were embedded at different cover depths of 4 , $5,6,10,15$ and $20 \mathrm{~mm}$ ( 2 sensors in each sample). The $\mathrm{IrO}_{\mathrm{x}}$ sensors were embedded in different mortar samples to increase the reliability of the results, which could be 
impaired by the variability in mortar properties, e.g. microstructure, at the different locations. Different cover depths were chosen to obtain $\mathrm{pH}$ profiles. The mortar mix proportions were the same as indicated in section 2.1. One hour after the mortar prisms (with the embedded $\operatorname{IrO}_{x}$ sensors) were cast, another $2.5 \mathrm{~cm}$ thick mortar layer with an embedded $\mathrm{Ag} / \mathrm{AgCl}$ ion-selective electrode was cast on top of the previous samples. This match-cast part contained $4 \%$ of admixed chlorides by weight of cement to ensure that the $\mathrm{Ag} / \mathrm{AgCl}$ electrode exhibits a stable potential [21] and thus could serve as internal reference electrode. The distance between the $\mathrm{IrO}_{\mathrm{x}}$ sensor embedded at "depth 2" (Fig. 2) and the $\mathrm{Ag} / \mathrm{AgCl}$ electrode was always higher than 4 $\mathrm{cm}$. Thus, it was not expected that significant amounts of chlorides would reach the $\mathrm{IrO}_{\mathrm{x}}$ sensors within the time of the current experiments.

The mortar prisms were cured for one week at 95\%RH and $21^{\circ} \mathrm{C}$. Subsequently, they were exposed for one week to laboratory conditions (ca. $50 \% \mathrm{RH}$ and $21^{\circ} \mathrm{C}$ ). Afterwards, all the surfaces (except one) were painted with an epoxy-resin and the samples were then placed in a carbonation chamber (65\%RH, $21^{\circ} \mathrm{C}$ and $4 \% \mathrm{CO}_{2}$ ) so one- dimensional carbonation occurred though the non-coated surface (Fig. 2).

The potential of the internal reference electrode $(\mathrm{Ag} / \mathrm{AgCl}$ ISE) was periodically checked with an $\mathrm{Ag} / \mathrm{AgCl} / \mathrm{sat} . \mathrm{KCl}$ external reference electrode that was inserted in the upper opening ("hole for contact with external RE" in Fig. 2). A drop of simulated pore solution $\left(0.15 \mathrm{~mol} \cdot \mathrm{L}^{-1} \mathrm{NaOH} 0.2 \mathrm{~mol} \cdot \mathrm{L}^{-1}\right.$ $\mathrm{KOH}$ and sat. $\left.\mathrm{Ca}(\mathrm{OH})_{2}\right)$ was used to establish electrolytic contact between the reference electrode and the mortar surface. The liquid junction potential was estimated to ca. 5 $\mathrm{mV}$ and the measured potential was corrected accordingly [22]. Between measurements, the upper opening was closed with a rubber plug to avoid carbonation of the mortar located in the hole. The main features of the set-up are shown in Fig. 2.

The potential of the embedded $\operatorname{IrO}_{x}$ sensors was continuously measured (with a time interval of 1 hour) versus the embedded reference electrode ( $\mathrm{Ag} / \mathrm{AgCl} I S E)$ with a Campbell data logger with $1 \mathrm{M} \Omega$ input impedance, which was connected to a computer for data acquisition. When the calculated $\mathrm{pH}$ (see section 2.2.3) at a certain selected sensor location was $\mathrm{pH} \approx 9.7$, the sample was split perpendicular to the surface of $\mathrm{CO}_{2}$ ingress and thymolphthalein indicator solution (see section 2.1) was sprayed on both freshly broken surfaces. The carbonation depth was determined from the average of 10 measurements of the depth of color change (5 measurements for each exposed surface).

\subsubsection{Algorithm for $\mathrm{pH}$ determination}

In concrete, diffusion potentials can be present due to internal concentration gradients, such as differences in $\mathrm{pH}$ or chloride concentration [22-24]. In this work, diffusion potentials were established between the internal reference electrode and $\mathrm{IrO}_{\mathrm{x}}$ sensors due to differences in chloride concentration (as the mortar with embedded $\mathrm{Ag} / \mathrm{AgCl}$ ISE contains chlorides, see section 2.2.2) and due to $\mathrm{pH}$ gradients (due to the progressive carbonation of the cement paste). Diffusion potentials thus varied as the $\mathrm{pH}$ of the pore solution changed due to carbonation. The potential measured $E_{\text {measured }}$ for each $\mathrm{IrO}_{\mathrm{x}}$ sensor is:

$E_{\text {measured }}=E_{\text {IrO }_{\mathrm{x}}}(p H)+E_{\text {diffusion }}(p H)-E_{\mathrm{Ag} / \mathrm{AgCl} \mathrm{ISE}}$

where $E_{\mathrm{Ag} / \mathrm{AgCl} \text { ISE }}$ is the potential of the $\mathrm{Ag} / \mathrm{AgCl}$ ISE internal reference electrode [21].

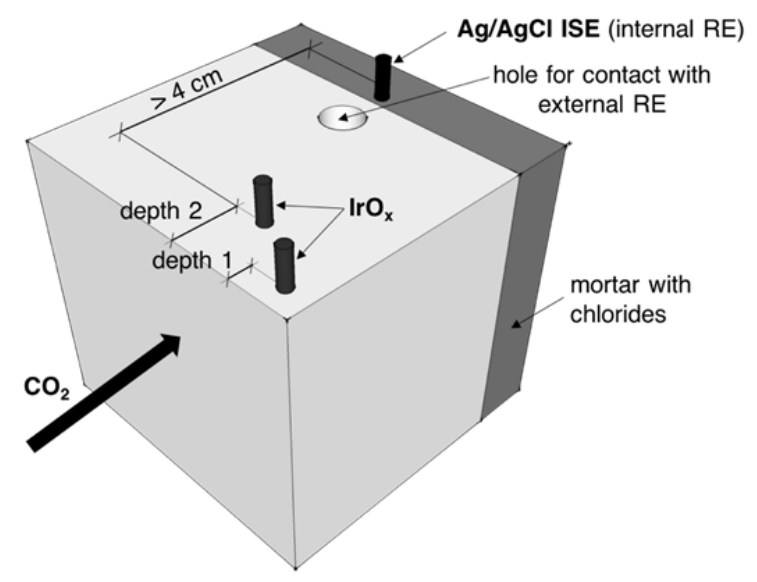

Figure 2. Illustration of the mortar samples used to monitor carbonation propagation with embedded $\mathrm{IrO}_{\mathrm{x}}$ sensors. All the surfaces were coated with epoxy resin with the exception of the surface of $\mathrm{CO}_{2}$ ingress. Each sample contained $2 \mathrm{IrO}_{\mathrm{x}}$ sensors at different depths. A chloride containing layer of mortar with an embedded $\mathrm{Ag} / \mathrm{AgCl}$ electrode was used to provide an embedded reference electrode (see text for explanation).

The diffusion potential $E_{\text {diffusion }}$ was calculated with the Henderson equation as described elsewhere [25]. For the calculation, the mobility of chloride and hydroxide ions was taken from the data reported in aqueous solution [25]. The concentration of hydroxide ions was related to the $\mathrm{pH}$ through the activity coefficient, obtained from the reported values in aqueous solution [26]. More information on the diffusion potentials in concrete and its evaluation can be found in literature [22-24, 27, 28].

Due to the interdependence of $\mathrm{pH}, E_{\mathrm{IrO}_{\mathrm{x}}}(p H)$ and $E_{\text {diffusion }}(p H)$ (Eq. (2)), no closed solution can be given and an iterative calculation procedure (Fig. 3) was used. In this calculation, $E_{\mathrm{IrO}_{\mathrm{x}}}(p H)$ was initially calculated assuming that $E_{\text {diffusion }}(p H)=0$. The $\mathrm{pH}$ was then determined from the calibration curve of the $\operatorname{IrO}_{x}$ electrode (Eq. (1)). Subsequently, $E_{\text {diffusion }}(p H)$ was calculated with this $\mathrm{pH}$ value and $E_{\mathrm{IrO}_{\mathrm{x}}}(p H)$ was re-calculated according to Eq. (2). This procedure was repeated until the $\mathrm{pH}$ difference between two consecutive iterations became $<0.1$.

Note that the $\mathrm{pH}$ at the $\mathrm{Ag} / \mathrm{AgCl}$ ISE $p H_{\mathrm{Ag} / \mathrm{AgCl} \mathrm{ISE}}\left(p H_{\mathrm{Ag} / \mathrm{AgCl} \text { ISE }} \approx\right.$ 13.5) was obtained from the first measurement (assuming that the $\mathrm{pH}$ of the pore solution was initially homogeneous for all the sample) when the mortar sample was placed in 
the carbonation chamber, i.e., $<1$ hour in the carbonation chamber.

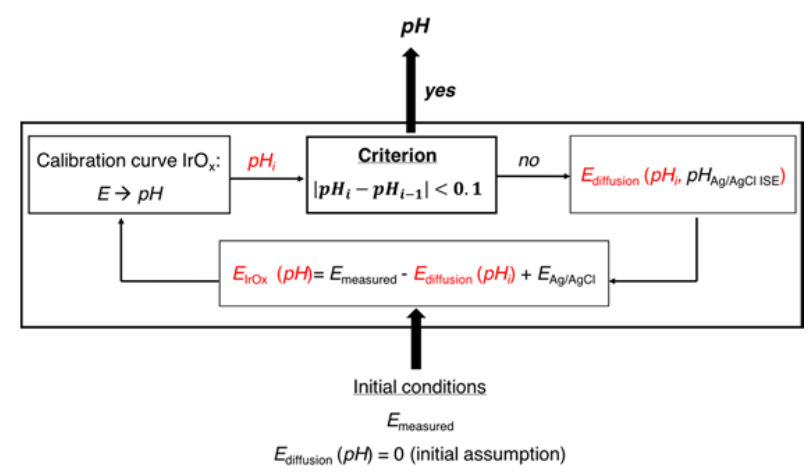

Figure 3. Representation of the iterative calculation procedure used to determine the $\mathrm{pH}$ of the pore solution with embedded $\mathrm{IrO}_{\mathrm{x}}$ sensors as the mortar sample carbonates. The parameters changed in each iteration are indicated in red. The calculated $\mathrm{pH}$ in each iteration $\left(p H_{i}\right)$ is specifically indicated in the diagram.

As an example, the calculated diffusion potential as a function of the $\mathrm{pH}$ for the $\mathrm{IrO}_{\mathrm{x}}$ sensor embedded at $15 \mathrm{~mm}$ cover depth is shown in Fig. 4.

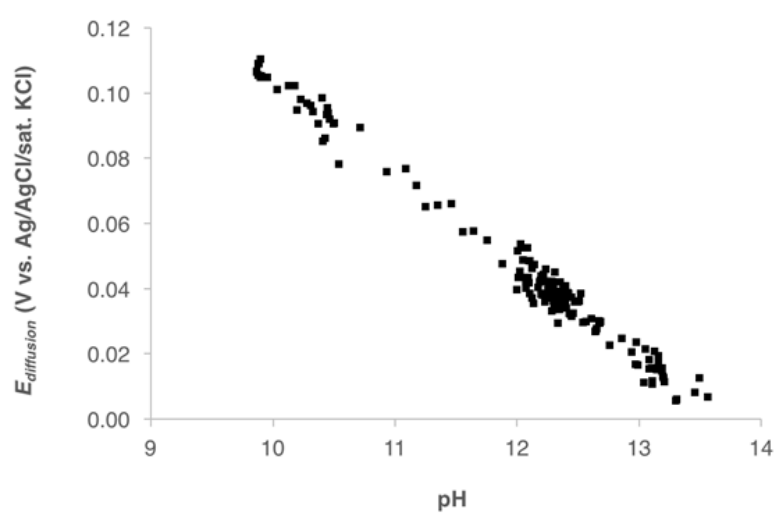

Figure 4. Example of calculated diffusion potential as a function of $\mathrm{pH}$ for the $\mathrm{IrO}_{\mathrm{x}}$ sensor embedded at $15 \mathrm{~mm}$ cover depth.

The diffusion potential increases as the $\mathrm{pH}$ gradient (between $\mathrm{IrO}_{\mathrm{x}}$ sensor and embedded reference electrode $\mathrm{Ag} / \mathrm{AgCl} \mathrm{ISE}$ ) increases, reaching potentials up to ca. $100 \mathrm{mV}$ (Fig. 4). Considering a theoretical $E-p H$ slope of $-0.059 \mathrm{~V} / \mathrm{pH}$ for the $\mathrm{IrO}_{\mathrm{x}}$ electrode, it can be deduced that relying on the experimentally measured potential without corrections, the real $\mathrm{pH}$ decrease from 13.5 to 9 would only be registered as a drop of ca. $2 \mathrm{pH}$ units. Thus, taking into account diffusion potentials in the calculation procedure forms an essential part of the $\mathrm{pH}$ measurement methodology in mortar or concrete.

\section{Results}

\subsection{Carbonation of concrete measured with embedded iridium/iridium oxide $\left({\left.\text { ( } \mathrm{O}_{\mathrm{x}}\right)}\right.$ sensors}

Fig. $5 a$ shows the calculated $\mathrm{pH}$ as a function of the square root of time in the carbonation chamber for six $\mathrm{IrO}_{\mathrm{x}}$ sensors embedded at cover depths 4, 5, 6, 10, 15 and $20 \mathrm{~mm}$. Note that curves with same color correspond to the same mortar sample. Fig. $5 b$ shows a representative example $\left(\mathrm{IrO}_{x}\right.$ sensor embedded at depth $6 \mathrm{~mm}$ ) of the $\mathrm{pH}$ decrease from $\mathrm{pH} \approx 14$ down to $\mathrm{pH} \approx 12$ as a function of time in the carbonation chamber.

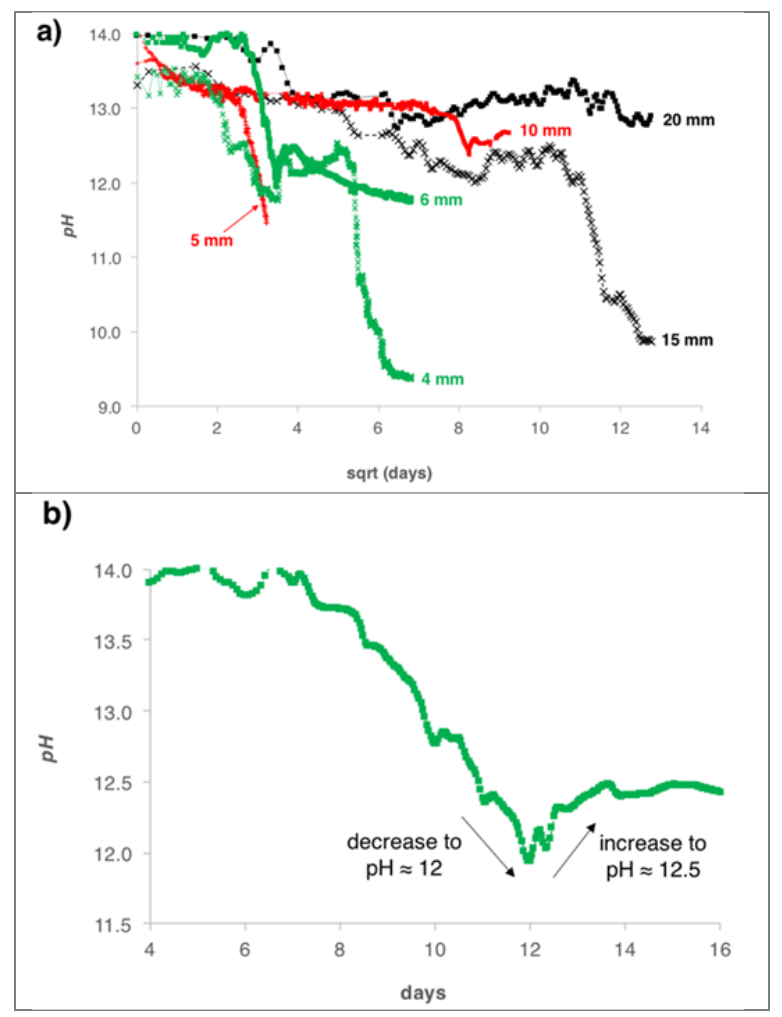

Figure 5. (a) Calculated $\mathrm{pH}$ as a function of the square root of time in the carbonation chamber for six $\mathrm{IrO}_{\mathrm{x}}$ sensors embedded at cover depths $4,5,6,10,15$ and $20 \mathrm{~mm}$. The curves with same color correspond to the same mortar sample (b) Representative example (IrO $\mathrm{r}_{\mathrm{x}}$ sensor embedded at $6 \mathrm{~mm}$ cover depth) showing the decrease from $\mathrm{pH} \approx 14$ down to $\mathrm{pH} \approx 12$, followed by a fast increase to $\mathrm{pH} 12.5$.

From Fig. 5a, it can be observed that for the sensors embedded at depths 4,5 and $6 \mathrm{~mm}$, the $\mathrm{pH}$ decreased from 13.5 to ca. 12.5 with a relatively sharp drop. In contrast, the sensors embedded at higher cover depths $(10,15$, and 20 $\mathrm{mm}$ ) showed a gradual $\mathrm{pH}$ decrease. In all cases, the $\mathrm{pH}$ initially decreased from its initial value to ca. $\mathrm{pH} \approx 12$, with a subsequent increase back to $\mathrm{ca}$. $\mathrm{pH} 12.5$ within a few days (Fig. 5b) and remained constant at that $\mathrm{pH}$ for some time. Afterwards, the $\mathrm{pH}$ rapidly decreased down to $\mathrm{pH} \approx 9.5$, as it can be observed for the results obtained for the sensors embedded at 4 and $15 \mathrm{~mm}$ cover depths (Fig. 5a). 


\subsection{Comparison between $\mathrm{pH}$ determined with embedded $\mathrm{IrO}_{\mathrm{x}}$ sensors and with $\mathrm{pH}$ - indicator solution}

One of the main advantages of the sensors used in this work is that they permit measuring the $\mathrm{pH}$ evolution of the pore solution continuously. Thus, the time needed to reach a certain $\mathrm{pH}$ (e.g. 12.5) at a given depth during the carbonation process can be determined - a big advantage over the traditional indicator spray method. Fig. 6 compares the relationship between depth and time for $\mathrm{pH} 12.5$ and $\mathrm{pH} \approx 9.7$ determined with the sensor, together with the relationship between depth and time for $\mathrm{pH}$ 9-10 determined with the indicator. Note that the time to reach $\mathrm{pH} 12.5$ corresponds to the first drop to this $\mathrm{pH}$ value. These two values were selected because $\mathrm{pH} 12.5$ is a characteristic value (see Fig. 5 ) at which the $\mathrm{pH}$ remains constant for some time (at least in Portland cement systems); and because $\mathrm{pH}$ 9-10 corresponds to the value detected with help of the indicator spray test (thymolphthalein). Additionally, from thermodynamic calculations, $\mathrm{pH} 9.7$ corresponds to the complete carbonation of $\mathrm{Ca}(\mathrm{OH})_{2}$ and ettringite and to the partial decalcification of the C-S-H phase $[29,30]$. Note that both cases can be approximated by a linear relationship between depth to reach a given $\mathrm{pH}$ and the square root of time.

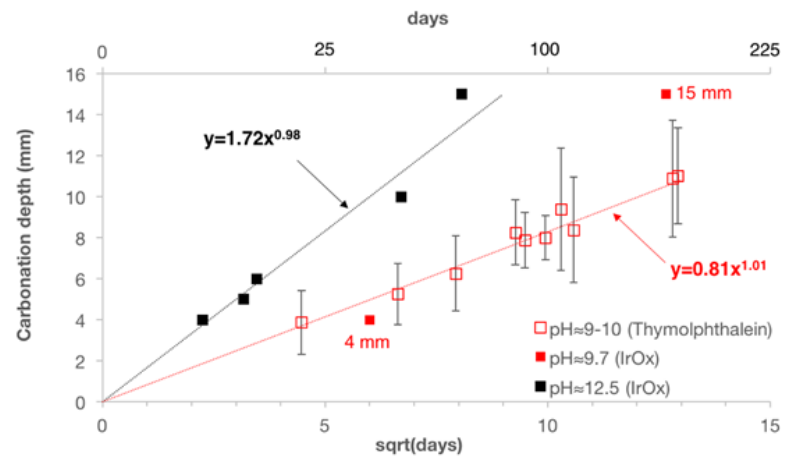

Figure 6. Carbonation depth at $\mathrm{pH} \approx 12.5$ and $\mathrm{pH} \approx 9.7$ (obtained with the embedded $\mathrm{IrO}_{\mathrm{x}}$ sensors) and at $\mathrm{pH}$ 9-10 (average of the individual measurements of the thymolphthalein spraying test, together with the standard deviation, indicated with the error bars) as a function of the square root of time in the carbonation chamber. The linear regression curves for the carbonation front at $\mathrm{pH} \approx 12.5$ and at $\mathrm{pH} \approx 9-10$ (obtained with the $\mathrm{pH}$ indicator) are indicated with dotted lines.

From Fig. 6, it can be seen that the carbonation front corresponding to $\mathrm{pH} \approx 12.5$, determined with the sensor, propagates significantly faster than the carbonation front at pH 9-10, determined with the indicator. Additionally, Fig. 6 shows that the $\operatorname{IrO}_{x}$ sensors indicate the carbonation at very similar times (result from the $\mathrm{IrO}_{\mathrm{x}}$ sensor embedded at $4 \mathrm{~mm}$ cover depth, which is within the standard deviation of the indicator spray test) or at earlier times (result from the $\mathrm{IrO}_{\mathrm{x}}$ sensor embedded at $15 \mathrm{~mm}$ cover depth) compared to the indicator spray test.

\section{Discussion \\ 4.1 $\mathrm{pH}$ evolution during carbonation process- the carbonation mechanism}

The studied $\mathrm{IrO}_{\mathrm{x}}$ sensor permits, for the first time, studying in-situ the evolution of the pore solution $\mathrm{pH}$ during carbonation of the cement paste (Fig. 5). Our results revealed several features that are discussed here. First, the $\mathrm{pH}$ drops stepwise, at least at shallow depths, and remains for a long time on $\mathrm{pH}$ approx. 12.5. At higher cover depths, this drop in $\mathrm{pH}$ occurs more gradually. Additionally, the propagation of the carbonation front associated with $\mathrm{pH}$ 12.5 , determined with $\mathrm{IrO}_{\mathrm{x}}$ sensors, seems to be much faster than the propagation of the front associated with $\mathrm{pH} 9-10$ that is determined with the indicator spray test (Fig. 6).

It is believed that the observed differences regarding carbonation propagation at $\mathrm{pH} 12.5$ and at $\mathrm{pH}$ 9-10 are due to differences in the process of carbonation and due to the measuring method (embedded $\mathrm{IrO}_{\mathrm{x}}$ sensors vs. $\mathrm{pH}$-indicator test, described in section 4.2).

In the carbonation process of cement paste, the $\mathrm{CO}_{2}$ from the gas phase is first dissolved in the water film on the pore wall:

$\mathrm{CO}_{2}+\mathrm{H}_{2} \mathrm{O} \rightarrow \mathrm{H}_{2} \mathrm{CO}_{3}$

The following equilibrium is then established:

$\mathrm{H}_{2} \mathrm{CO}_{3}(\mathrm{aq}) \leftrightarrow \mathrm{H}^{+}(\mathrm{aq})+\mathrm{HCO}_{3}^{-}(\mathrm{aq}) \leftrightarrow 2 \mathrm{H}^{+}+\mathrm{CO}_{3}^{2}$

The resulting protons react with the $\mathrm{OH}^{-}$ions of the pore solution, leading to the observed initial $\mathrm{pH}$ decrease from $\mathrm{pH}$ $\approx 13.5$ to $\mathrm{pH} \approx 12.5$ (Fig. 5). The products of this early reaction are soluble $\mathrm{Na}^{+}$or $\mathrm{K}^{+}$carbonates $\left(\mathrm{CO}_{3}{ }^{2-}\right)$, the formation of which does not hinder further ingress of $\mathrm{CO}_{2}$. However, the fact that part of the $\mathrm{CO}_{2}$ in the gas phase is dissolved in the water film on the pore walls will lead to a decrease of the $\mathrm{CO}_{2}$ concentration at larger distances from the surface (filter effect). Replenishment of the $\mathrm{CO}_{2}$ concentration in the pores would then be governed by diffusion processes, resulting in the vt law (Fig. 6).

During the long time where the $\mathrm{pH}$ of the pore solution remains constant at $\mathrm{pH} \approx 12.5$ (Fig. 5), the $\mathrm{CO}_{3}{ }^{2-}$ ions react with the dissolved $\mathrm{Ca}^{2+}$ ions forming sparingly soluble $\mathrm{CaCO}_{3}$ (solubility product $K_{\mathrm{sp}}=3.36 \cdot 10^{-9}$ at $25^{\circ} \mathrm{C}$ [26]). As a consequence, the $\mathrm{Ca}^{2+}$ concentration in the pore solution would decrease but this is compensated by the $\mathrm{Ca}(\mathrm{OH})_{2}$ dissolution (Portlandite, solubility product $K_{\mathrm{sp}}=5.02 \cdot 10^{-6}$ at $25^{\circ} \mathrm{C}$ [26]). The possible formation of the $\mathrm{CaCO}_{3}$ coating on the Portlandite crystals $[10,11]$ can however, act as a barrier and hinder further Portlandite dissolution. In this regard, it may also be possible that the dissolution of $\mathrm{Ca}(\mathrm{OH})_{2}$ may be partially diffusion-controlled [31]. Thus, the kinetically limited dissolution of Portlandite, specially under conditions of accelerated carbonation, may be the reason why the $\mathrm{pH}$ of the pore solution initially decreased down to $\mathrm{pH} \approx 12$ 
before it increased and remained constant at $\mathrm{pH} \approx 12.5$ (Fig. 5).

Once all the $\mathrm{Ca}(\mathrm{OH})_{2}$ is consumed, the $\mathrm{pH}$ of the pore solution decreases down to $\mathrm{pH} \approx 10$. In this case, the reactions involve other cement phases, e.g. mainly $\mathrm{C}-\mathrm{S}-\mathrm{H}[10,11]$. Measurements with the $\operatorname{IrO}_{x}$ sensors results, at least, in a factor of 3 for the time needed to reach $\mathrm{pH} 9.7$ compared to the time needed to reach $\mathrm{pH} 12.5$ (compare results regarding the sensors embedded at 4 and $15 \mathrm{~mm}$, Fig. 6). For the sensors embedded at 5, 6, 10 and $20 \mathrm{~mm}$ cover depths, it can be seen that $\mathrm{pH} 9.7$ has not been reached yet (Fig. 5). From the above described carbonation mechanism, it is believed that early carbonation with the first $\mathrm{pH}$ decrease from $\mathrm{pH} \approx 13.5$ to $\mathrm{pH} \approx 12.5$ is mainly governed by the kinetics of $\mathrm{CO}_{2}$ transport into the pore system (diffusion-controlled), while the second $\mathrm{pH}$ decrease from 12.5 to about 9 is additionally determined by the kinetics of reaction of $\mathrm{CO}_{2}$ with the solid alkali reserve of the cement paste, resulting in much longer times. In this case, the $\mathrm{pH}$ drop is expected to occur later for higher amounts of Portlandite.

Additionally, it is known that carbonation propagation becomes slower with time, e.g. due to a densification of the pore structure over time [4], and possibly due to changes in cement paste microstructure during carbonation [32], at least in Portland Cement. This may result into slower diffusion of $\mathrm{CO}_{2}$ and longer times to reach $\mathrm{pH}$ 12.5. This could explain slower and gradual carbonation propagation at $\mathrm{pH} \approx 12.5$ at larger cover depths (e.g. sensors embedded at 10, 15 and 20 cover depths in Fig. 5) and stepwise and faster propagation at shallow cover depths (e.g. sensor embedded at 4, 5 and 6 cover depths in Fig. 5), as observed by Glass et al. [33] when studying the acid neutralization behavior of cement paste by adding different amounts of acid stepwise.

\subsection{Comparison between $\mathrm{pH}$ determined with embedded $\mathrm{IrO}_{x}$ sensors and by means of $\mathrm{pH}$-indicator solution}

From Fig. 6, clear differences can be observed regarding carbonation propagation measured with the sensor at $\mathrm{pH} \approx 12.5$ and with the indicator test at $\mathrm{pH} 9-10$. Apart from differences in the carbonation process (section 4.1), it is believed that these differences are also due to the measuring method. We believe that the electrode detects the $\mathrm{pH}$ locally in the pore solution, whereas the indicator sprayed on a freshly split surface can become blue $(\mathrm{pH}>9-10)$ when not yet fully carbonated Portlandite particles react with the indicator solution. Thus, the sensor may show a pH drop earlier than or at the same time as the indicator, but in principle never later.

Additionally, it should be noted that the differences may also be due to the accuracy of the method used. The maximum error for the $\mathrm{pH}$ determined with $\mathrm{IrO}_{x}$ sensors is $<0.5 \mathrm{pH}$ units [20], whereas the accuracy of the $\mathrm{pH}$ indicator is roughly $1 \mathrm{pH}$ unit and the carbonation front determined with the indicator on OPC mortar is quite blurry (see the high standard deviations in Fig. 6), a fact that can be associated to a transition zone (thickness of about $2-3 \mathrm{~mm}$ ) where $\mathrm{CaCO}_{3}$ and $\mathrm{Ca}(\mathrm{OH})_{2}$ are coexisting $[10,11]$.

\subsection{Implications and outlook of the obtained results}

\subsubsection{Relation to natural carbonation}

The relationship between the carbonation depth $d$ and the square root of time, shown in Fig. 6 , can be described with a linear law, in the form [4]:

$d=K_{\mathrm{acc}, 4 \%} \cdot \sqrt{\mathrm{t}}$

where $K_{a c c, 4 \%}$ is the carbonation coefficient in the present accelerated conditions.

For the carbonation front determined with the indicator test $(\mathrm{pH} \approx 9-10), \quad K_{\text {acc } 4 \%}$ is equal to approx. $16 \mathrm{~mm} /$ year $^{1 / 2}$ (corresponding to $0.81 \mathrm{~mm} / \mathrm{day}^{1 / 2}$ ), in agreement with values reported in the literature for porous concrete [34]. For the carbonation front at $\mathrm{pH} 12.5$ determined with the sensor, $K_{\text {acc } 4 \%}$ is approx. $31 \mathrm{~mm} /$ year $^{1 / 2}$ (corresponding to $1.72 \mathrm{~mm} / \mathrm{day}^{1 / 2}$ ), thus much higher than the results of the indicator test.

Based on the experimentally determined carbonation coefficients, an extrapolation to much longer times can be made. The result is shown in Fig 7a both for the carbonation front associated with $\mathrm{pH} 12.5$ and the carbonation front determined with the indicator test at $\mathrm{pH}$ 9-10. In Fig. 7b, a schematic representation of the different carbonation fronts at $\mathrm{pH} 12.5$ and at $\mathrm{pH}$ 9-10 is shown.

From Fig. 7a, it can be seen that for the present experimental conditions, the carbonation depth at $\mathrm{pH} \approx 12.5$ will reach a cover depth of $15 \mathrm{~mm}$ (minimum cover depth for exposure condition XC3) in about 3 months, whereas it will take about one year to detect a pH below 10 at the same cover depth with the indicator spray test. For natural carbonation in sheltered outdoor conditions, the carbonation coefficients have been found to be about 6-8 times lower compared to accelerated carbonation with $4 \%$ $\mathrm{CO}_{2}$ (for relatively porous Portland cement concrete $(\mathrm{w} / \mathrm{c}=$ 0.65)) [34]. With lower w/c ratio, this factor increased. As a first-hand estimate for our case, with a relatively porous mortar (Portland cement, $w / c=0.5$, only one week curing), this factor may be approx. 10 . Thus, to reach pH 12.5 at 15 $\mathrm{mm}$, about 23 years would be necessary, whereas this time would be extended to about 100 years to reach full carbonation at $\mathrm{pH}$ 9-10 (detectable with the indicator spray test). Denser concrete pore structures and exposure to unsheltered conditions might significantly increase these times. Nevertheless, this indicates that after only a few decades (long before the designed service life), the concrete is carbonated down to $\mathrm{pH} 12.5$ at cover depths in agreement with EN 206-1 for XC exposure conditions. 


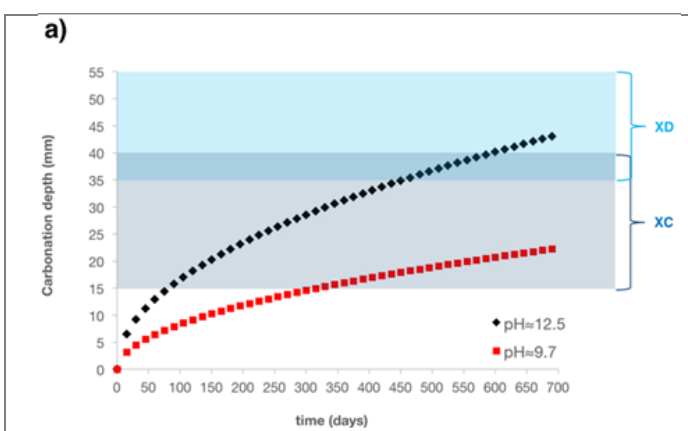

b)

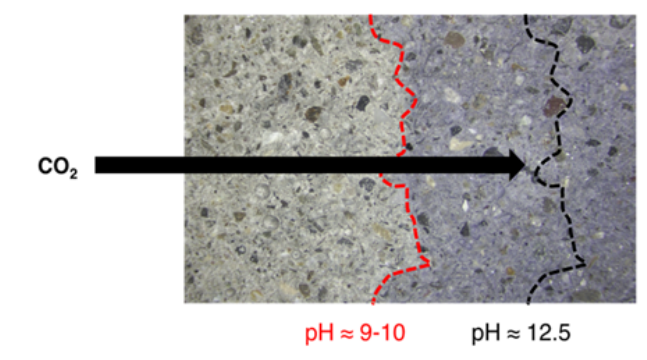

Figure 7. (a) Carbonation front associated with $\mathrm{pH} 12.5$ ( $\mathrm{IrO}_{\mathrm{x}}$ sensor) and with $\mathrm{pH} \approx 9-10$ (indicator spray test) from the fitted curves obtained from accelerated carbonation tests (Fig. 6). The range of minimum cover depth for XC (carbonation-induced-corrosion) and for XD (chloride induced corrosion) exposure classes according to EN 206-1 [35] are also indicated in the graph (b) Schematic representation of the carbonation front in concrete at a certain point in time.

\subsubsection{Implication on corrosion of the reinforcement}

The significantly shorter time for the concrete to be carbonated down to $\mathrm{pH} 12.5$ (from initially about 13.5) than down to $\mathrm{pH}$ 9-10 has implications for the corrosion of the embedded reinforcing steel bars. The indicator test used in condition assessment of structures [36] with a colour change in the range of $\mathrm{pH} 9-10$ is usually believed to confirm that the reinforcement is still in alkaline concrete (tacitly assumed as about 13.5 in OCP concrete). However, the level of alkalinity may play a crucial role in the presence of even low amounts of chloride, where a difference between $\mathrm{pH} 13.5$ and 12.5 can be decisive. Based on the critical ratio of chloride and hydroxide ions needed to trigger corrosion, as proposed by Hausmann [5] $\left(\mathrm{Cl}^{-} / \mathrm{OH}^{-}=0.6\right)$, a pH of about 13.5 corresponds to a critical chloride concentration for corrosion initiation of about $0.2 \mathrm{~mol} \cdot \mathrm{L}^{-1}$. At $\mathrm{pH} 12.5$, on the other hand, the tolerable chloride concentration is one order of magnitude lower, that is only about $0.02 \mathrm{~mol} \cdot \mathrm{L}^{-1}$. This value might be reached due to chlorides in the raw materials or as free chloride content when $0.4 \%$ total chloride ions by weight of cement are present as is apparent from various studies investigating chloride binding in concrete [37, 38]. Thus, chloride-induced corrosion of the reinforcement in structures exposed to carbonation might occur at much lower chloride concentrations than usually considered for "uncarbonated" concrete. However, this situation is usually not studied in laboratory testing of chloride induced corrosion; due to the comparatively short durations of testing, the $\mathrm{pH}$ at the steel surface may still be above 13 .

\subsubsection{Outlook: study of blended cements}

Another possible application of the $\mathrm{pH}$ sensors presented in this work could be the study of the kinetics of carbonation of blended cements. In these cements, the Portlandite content $\left(\mathrm{Ca}(\mathrm{OH})_{2}\right.$ phase) is lower due to the substitution of the clinker by SCMs. While this may have only a small influence on the $\mathrm{pH}$ of the pore solution [3], the $\mathrm{pH}$ buffer capacity around $\mathrm{pH} \approx 12.5$ may be significantly impaired, e.g., the time during which the system exhibits constant $\mathrm{pH} \approx 12.5$ is expected to strongly depend on the type of binder used. Our sensors permit directly characterizing this by measuring the time during which a certain system resists a decrease in $\mathrm{pH}$ below 12.5. In contrast to titration methods or thermodynamic modeling, our sensors, being embedded at different depths, permit assessing the combined effects of transport of $\mathrm{CO}_{2}$ through the increasingly carbonated and thus microstructurally affected cover as well as the kinetics of the carbonation reactions in a given real system. This is expected to increase considerably the practice-relevance of the results.

\section{Conclusions}

In this work, we used embedded $\operatorname{IrO}_{x}$ sensors to continuously monitor in-situ the $\mathrm{pH}$ in mortar specimens subjected to accelerated carbonation. To this aim, we suggested an iterative calculation algorithm that takes into diffusion potentials and thus permits determining the $\mathrm{pH}$ at any depth; this algorithm forms an essential part of the $\mathrm{pH}$ measuring method.

The main implications from the obtained results are:

- The shape of the $\mathrm{pH}$ vs time curve upon carbonation was found to exhibit a number of characteristic features including a $\mathrm{pH}$ decrease in steps, with the $\mathrm{pH}$ remaining on certain levels for different amounts of times, and a dependency on the cover depth. These $\mathrm{pH}$ vs time measurements can give substantial insight in to the process of carbonation.

- The stepwise decrease was found in agreement with literature data, e.g. from "titration tests" or thermodynamic modeling. In contrast to these approaches, however, the used $\mathrm{pH}$ sensors also permit considering time-dependent processes, such as $\mathrm{CO}_{2}$ transport or the kinetics of phase transformations in the cement paste.

- We suggest that the measurement of the time during which the $\mathrm{pH}$ of the pore solution remains constant at $\mathrm{pH} 12.5$ while cement paste carbonates may present a novel means to characterize blended cements (with lower Porlandite content);

- The carbonation front at $\mathrm{pH} 12.5$ is much ahead of the front at $\mathrm{pH}$ 9-10, which is the carbonation front usually determined with common indicator spray tests. At $\mathrm{pH}$ 12.5 , the risk of chloride-induced corrosion greatly increases, but this situation is usually not detected in 
the field and rarely studied in laboratory testing. The possibility to monitor $\mathrm{pH}$ evolution over time under field conditions has major implications for the durability of reinforced concrete structures.

\section{References}

[1] Condition control and assessment of reinforced concrete structures exposed to corrosive environments, State-of-art report, International Federation of Structural Concrete (FIB), Task group 5.8. (2011).

[2] A.M. Neville, Properties of Concrete, 5th ed., Harlow, Pearson Education Limited. (2011).

[3] A. Vollpracht, B. Lothenbach, R. Snellings, J. Haufe, The pore solution of blended cements: a review. Mater Struct (2015) 49: 3341-3367. https://doi.org/10.1617/s11527-015-0724-1

[4] L. Bertolini, B. Elsener, P. Pedeferri, E. Redaelli, R.P. Polder, Corrosion of steel in concrete, second ed., Weinheim, Wiley. (2013). https://doi.org/10.1002/9783527651696

[5] D.A. Hausmann, Corrosion of steel in concrete. How does it occur?. J Mater Prot (1967) 6: 19-23.

[6] G. Plusquellec, M.R. Geiker, J. Lindgård, J. Duchesne, B. Fournier, K.D. Weerdt, Determination of the $\mathrm{pH}$ and the free alkali metal content in the pore solution of concrete: Review and experimental comparison. Cem Concr Res (2017) 96: 13-26. https://doi.org/10.1016/j.cemconres.2017.03.002

[7] A. Behnood, K.V. Tittelboom, N.D. Belie, Methods for measuring pH in concrete: A review. Constr Build Mater (2016) 105: 176-188. https://doi.org/10.1016/j.conbuildmat.2015.12.032

[8] M.-Y. Yu, J.-Y. Lee, C.-W. Chung, The application of various indicators for the estimation of carbonation and $\mathrm{pH}$ of cement based materials. J Test Eval (2010) 38: 534-540. https://doi.org/10.1520/JTE102382

[9] E. Liu, M. Ghandehari, C. Brückner, G. Khalil, J. Worlinsky, W. Jin, A. Sidelev, M.A. Hyland, Mapping high pH levels in hydrated calcium silicates. Cem Concr Res (2017) 95: 232-239. https://doi.org/10.1016/j.cemconres.2017.02.001

[10] M. Thiery, G. Villain, P. Dangla, G. Platret, Investigation of the carbonation front shape on cementitious materials: Effects of the chemical kinetics. Cem Concr Res (2007) 37: 1047-1058 https://doi.org/10.1016/j.cemconres.2007.04.002

[11] Geoffrey W. Groves, Adrian Brough, lan G. Richardson, C.M. Dobson, Progressive changes in the structure of hardened C3S cement pastes due to carbonation. J Am Ceram Soc (1991) 74: 2891-2896. https://doi.org/10.1111/j.1151-2916.1991.tb06859.x

[12] S. Yao, M. Wang, M. Madou, A pH electrode based on meltoxidized iridium oxide. J Electrochem Soc (2001) 148: H29-H36. https://doi.org/10.1149/1.1353582

[13] W.-D. Huang, H. Cao, S. Deb, M. Chiao, J.C. Chiao, A flexible pH sensor based on the iridium oxide sensing film. Sens Actuators (2011) A 169: 1-11. https://doi.org/10.1016/j.sna.2011.05.016

[14] S.A.M. Marzouk, S. Ufer, R.P. Buck, T.A. Johnson, L.A. Dunlap, W.E. Cascio, Electrodeposited iridium oxide $\mathrm{pH}$ electrode for measurement of extracellular myocardial acidosis during acute ischemia. Anal Chem (1998) 70: 5054-5061. https://doi.org/10.1021/ac980608e

[15] W. Olthuis, M.A.M. Robben, P. Bergveld, M. Bos, W.E.V.d. Linden, $\mathrm{pH}$ sensor properties of electrochemically grown iridium oxide. Sens Actuators (1990) B 2: 247-256. https://doi.org/10.1016/0925-4005(90)80150-X

[16] R.-G. Du, R.-G. Hu, R.-S. Huang, C.-J. Lin, In situ measurement of $\mathrm{Cl}^{-}$ concentrations and $\mathrm{pH}$ at the reinforcing steel/concrete interface by combination sensors. Anal Chem (2006) 78: 3179-3185. https://doi.org/10.1021/ac0517139

[17] S.-G. Dong, C.-J. Lin, R.-G. Hu, L.-Q. Li, R.-G. Du, Effective monitoring of corrosion in reinforcing steel in concrete constructions by a multifunctional sensor. Electrochim Acta (2011) 56: 1881-1888. https://doi.org/10.1016/j.electacta.2010.08.089

[18] M. Wang, S. Yao, M. Madou, A long-term stable iridium oxide $\mathrm{pH}$ electrode. Sens Actuators (2002) B 81: 313-315. https://doi.org/10.1016/S0925-4005(01)00972-8

[19] M. Wang, S. Yao, Carbonate-Melt Oxidized Iridium Wire for $\mathrm{pH}$ Sensing. Electroanalysis (2003) 15: 1606-1615. https://doi.org/10.1002/elan.200302723
[20] Y. Seguí Femenias, U. Angst, B. Elsener, Monitoring pH in corrosion engineering by means of thermally-produced iridium oxide electrodes. Mater Corros (2017) in press. https://doi.org/10.1002/maco.201709715

[21] Y. Seguí Femenias, U. Angst, F. Caruso, B. Elsener, $\mathrm{Ag} / \mathrm{AgCl}$ ionselective electrodes in neutral and alkaline environments containing interfering ions. Mater Struct (2016) 49: 2637-2651. https://doi.org/10.1617/s11527-015-0673-8

[22] U. Angst, $\varnothing$. Vennesland, R. Myrdal, Diffusion potentials as source of error in electrochemical measurements in concrete. Mater Struct (2009) 42: 365-375. https://doi.org/10.1617/s11527-008-9387-5

[23] R. Myrdal, Phenomena that disturb the measurement of potentials in concrete, Corrosion/96, NACE International, Paper No.339 (1996).

[24] R. Myrdal, Potential gradients in concrete caused by charge separations in a complex electrolyte, Corrosion/97, NACE International, Paper No.278 (1997).

[25] A.J. Bard, L.R. Faulkner, Electrochemical methods: fundamentals and applications, second ed., New York, Willey (2001).

[26] W.M. Haynes, Handbook of chemistry \& physics, ninety fourth ed., Boca Raton, CRC Press (2013-2014).

[27] U. Angst, B. Elsener, R. Myrdald, $\varnothing$. Venneslanda, Diffusion potentials in porous mortar in a moisture state below saturation. Electrochim Acta (2010) 55: 8545-8555. https://doi.org/10.1016/j.electacta.2010.07.085

[28] A. Atkinson, A.K. Nickerson, The diffusion of ions through watersaturated cement. J Mater Sci (1984) 19: 3068-3078. https://doi.org/10.1007/BF01026986

[29] Z. Shi, B. Lothenbach, M.R. Geiker, J. Kaufmann, A. Leemann, S. Ferreiro, J. Skibsted, Experimental studies and thermodynamic modeling of the carbonation of Portland cement, metakaolin and limestone mortars. Cem Concr Res (2016) 88: 60-72. https://doi.org/10.1016/j.cemconres.2016.06.006

[30] T.F. Sevelsted, J. Skibsted, Carbonation of $\mathrm{C}-\mathrm{S}-\mathrm{H}$ and $\mathrm{C}-\mathrm{A}-\mathrm{S}-\mathrm{H}$ samples studied by $13 \mathrm{C}, 27 \mathrm{Al}$ and $29 \mathrm{Si}$ MAS NMR spectroscopy. Cem Concr Res (2015) 71: 56-65. https://doi.org/10.1016/j.cemconres.2015.01.019

[31] D.E.Giles, I.M.Ritchie, B.-A.Xu, The kinetics of dissolution of slaked lime. Hydrometallurgy (1993)32: 119-128. https://doi.org/10.1016/0304-386X(93)90061-H

[32] A. Hidalgo, C. Domingo, C. Garcia, S. Petit, C. Andrade, C. Alonso, Microstructural changes induced in Portland cement-based materials due to natural and supercritical carbonation. J Mater Sci (2008) 43: 3101-3111. https://doi.org/10.1007/s10853-008-2521-5

[33] G.K. Glass, B. Reddy, N.R. Buenfeld, Corrosion inhibition in concrete arising from its acid neutralisation capacity. Corros Sci (2000) 42: 1587-1598. https://doi.org/10.1016/S0010-938X(00)00008-1

[34] A. Leemann, F. Moro, Carbonation of concrete: the role of $\mathrm{CO} 2$ concentration, relative humidity and $\mathrm{CO} 2$ buffer capacity. Mater Struct (2016) 50:30. https://doi.org/10.1617/s11527-016-0917-2

[35] CEN/TC-104, EN 206-1 Concrete - Part 1: Specification, performance, production and conformity (2000).

[36] SHRP-S-337, Cathodic protection of reinforced concrete bridge elements: a state of the art report, Strategic Highway Research Program, National Research Council (1993).

[37] T. Luping, L.O. Nilsson, Chloride binding capacity and binding isotherms of OPC pastes and mortars. Cem Concr Res (1993) 23 247-253. https://doi.org/10.1016/0008-8846(93)90089-R

[38] J. Tritthart, Chloride binding in cement I. Investigations to determine the composition of porewater in hardened cement. Cem Concr Res (1989)19: 586-594. https://doi.org/10.1016/0008-8846(89)90010-0 